\title{
Knowledge, Attitudes and Practices towards Ebola Virus Disease among Participants in an Ebola Vaccine Trial in Dakar, Senegal
}

Ndeye Aïssatou Lakhe ${ }^{1 *}$, Khardiata Diallo Mbaye ${ }^{1}$, Khadime Sylla $^{2}$, Ndeye Mery Dia Badiane ${ }^{3}$, Cheikh Tacko Diop ${ }^{4}$, Viviane Marie Pierre Cisse Diallo ${ }^{1}$, Daye $\mathrm{Ka}^{1}$, Louise Fortes Deguenonvo ${ }^{1}$, Cheikh Tidiane Ndour ${ }^{1}$, Masserigne Soumare ${ }^{1}$ and Moussa Seydi ${ }^{1}$

${ }^{1}$ Clinic of Infectious and Tropical Diseases, Fann National University Hospital, P.O. Box: 5035-Fann, Dakar, Senegal

${ }^{2}$ Parasitology-Mycology Service, Medecine Faculty, Cheikh Anta Diop University, P.O. Box: 5005-Fann, Dakar, Senegal

${ }^{3}$ Health Science Training Unit and Research, Gaston Berger University, Saint-Louis, Senegal

${ }^{4}$ Community Health Department, Health and Sustainable Development Training Unit and Research, Alioune Diop University, Bambey, Senegal

"Corresponding author: Ndeye Assatou Lakhe, Clinic of Infectious and Tropical Diseases, Fann National University Hospital, P.O. Box: 5035-Fann, Dakar, Senegal, Tel: +221 7754173 01; E-mail: aissatou.lakhe@ucad.edu.sn

Received date: June 06, 2018; Accepted date: August 21, 2018; Published date: August 30, 2018

Copyright: @ 2018 Lakhe NA, et al. This is an open-access article distributed under the terms of the Creative Commons Attribution License; which permits unrestricted use; distribution; and reproduction in any medium; provided the original author and source are credited.

\begin{abstract}
The 2014 Ebola outbreak in West Africa was the trigger to mobilize efforts in order to promptly obtain safe and effective vaccine. The objectives of this survey conducted during an Ebola vaccine trial were assessing the knowledge, attitudes and practices of participants about Ebola and vaccine and determining the association of key sociodemographic characteristics with knowledge of transmission mode, reservoir, stigma and hand washing. A cross sectional study was designed and a semi-closed questionnaire was used to collect data of the 250 participants. The main identified sources of information were television and radio. The motivations for being part of the study were confidence in doctors $(79.6 \%)$ and example given by the medical staff $(75.6 \%)$. Knowledge of transmission mode was low among respondents $(22.1 \%)$ while that on the reservoir was rather high $(73.8 \%)$. Stigma was noted in $49.2 \%$ of participants. Behavioural change through hand washing was adopted in $74.4 \%$ of respondents. Factors associated with knowledge of transmission mode were age group, urban origin, marital status and education level. Fear and geographic origin were associated to stigma and hand washing. To better prevent and control the spread of Ebola virus disease, a focus needs to be placed on modes of transmission and hand washing, and health personnel could play a major role in improving the acceptability of the vaccine.
\end{abstract}

Keywords: Knowledge; Attitudes; Practices; Ebola; Vaccine trial; Dakar; Senegal

\section{Introduction}

Ebola Virus Disease (EVD) is a highly contagious and redoubtable disease caused by five species of the virus, belonging to the genus filovirus. The disturbances of the forest ecosystem linked to human activities such as agriculture and forest exploitation are at the origin of modifications of the fauna which can be translated in West Africa by an increase in contacts "reservoir - intermediate host - Human" [1-3]. The speed and ease with which the disease is transmitted from human to human, are causing terrible epidemics. In order to stop the increase in the frequency of outbreaks of EVD, a more active search of the reservoir of the virus is necessary [4].

In 2014 for the first time, the virus seized outside of Central Africa to reach West Africa and outside the African continent. It was responsible for an unprecedented outbreak in West Africa, with Guinea, Sierra Leone and Liberia as the top three affected countries. Also, the spread of infected subjects extended to Europe through air travel (Spain, Germany) and to the United States of America (USA), the USA case being caused by an infected Liberian traveller from West Africa developing and also infecting USA medical personnel [5]. WHO described this epidemic as a "Public Health Emergency of International Concern (PHEIC)" based on the following four criteria: severity, unusual and unexpected nature, risk of international spread, and risk of restriction [6].
As of March 27, 2016, the number of cases reported worldwide was 26,646 of which 11,323 died giving a lethality of $39.5 \%$ [7]. In Senegal, an imported case was notified on 29 August 2014. From the beginning of the epidemic, a major communication campaign was launched through media with key messages focusing mainly on the signs and means of prevention of the disease including hand washing. That outbreak was the longest and deadliest since the discovery of the virus. One of the reasons justifying the magnitude of this epidemic was the lack of knowledge of the population on this condition, particularly on preventive measures [4].

Its socio-economic impact was considerable through the weakening of socio-political systems, psychological distress and the unprecedented consumption of already limited health resources [3]. The enormous economic impact is also related to the limitation of migratory movements linked to the closing of borders and the cessation of commercial activities [3]. The absence of etiological treatment and effective vaccines makes the research and development of antivirals and vaccines more indispensable and more urgent. Thus, through the Ebola Blueprint R\&D strategy, WHO has asked its various partners to fully commit themselves to testing, authorizing and making available safe and effective interventions against Ebola. In response to this call, an accelerated vaccine development effort was initiated. Although healthcare workers are the primary targets for Ebola immunization, mass vaccination strategies can be developed as means to protect populations and contain the epidemic. As such, a clinical trial was conducted in Guinea, which final results confirm that Ebola vaccine offers high protection against the disease [8]. Like other 
countries, Senegal hosted a vaccine trial against Ebola. The Infectious and Tropical Diseases Clinic (SMIT) of Fann Hospital from August 2015 was one of the two Senegalese sites of this trial.

This survey of participants was conducted during this study. The main objective was to assess the knowledge, practices and attitudes towards EVD of these participants. The secondary objectives were to identify key sociodemographic factors associated with knowledge of reservoir and transmission mode, with stigma and increase of hand washing.

\section{Material and Methods}

\section{Site, period and type of study, participants}

This study was conducted at the Infectious and Tropical Diseases Clinic (SMIT: Service des Maladies Infectieuses et Tropicales) at Fann Teaching University Hospital, specifically at the Ebola vaccine trial division. Indeed, in this site, a randomized, blinded, observercontrolled, Phase 2 study was conducted to evaluate the safety and immunogenicity of a single intramuscular dose of the recombinant adenovirus vector vaccine of type 3 chimpanzee against the Zaire strain of Ebola virus (ChAd3-EBO-Z) developed by GSK Biologicals (GSK3390107A) in adult in Africa.

A cross-sectional study was performed from 3 August to 2 November 2015 among participants of this vaccine trial.

\section{Quantitative data collection}

After explaining the objectives of the survey, participants who gave their consent were included and the questionnaire administered to them.

This questionnaire was previously pre-tested with people who came to the SMIT consultation unit to ensure understanding and clarity of the questions. Then, it underwent minor changes which proved to be satisfactory as the questionnaire was finally found more understandable, without ambiguity. Thus it was administered in Wolof and in French by a trained investigator and by direct interview. The questionnaire consisted of 39 questions divided into four sectionss: (i) socio-demographic characteristics, (ii) perceptions, (iii) knowledge of EVD and vaccination, and (iv) attitudes and practices regarding EVD. The questions were mostly close-ended and for some, the answers were open.

Knowledge of virus reservoir was defined as good if participants identified monkeys and bats involvement in transmission otherwise it was poor. Regarding knowledge of transmission mode, it was labelled as good if transmission mode was contact with Ebola deceased patient, contact with body fluids of a person who is sick of EVD and eating bush meat.

Stigmatization was defined as positive if respondents avoided citizen from countries affected by EVD or demanded closing borders to these nationals.

\section{Quantitative statistical analysis}

The data obtained were entered using Epidata software version 3.1. then transferred for analysis to Stata software (Stata / SE 12.1 for Mac, StataCorp, College Station, TX). The descriptive analysis included the calculation of absolute values and proportions for categorical variables and the median or mean (with SD or IQR) for quantitative variables. Regarding the analytical study, to compare the proportions, we used
Chi2 test (Pearson and Yeates). Student's test was used for the comparison of quantitative variables. Any difference with a p-value less than 0.05 were considered statistically significant.

\section{Ethics consideration}

This study was reviewed and approved by the National Ethics Committee (Conseil National d'Ethique et de Recherche en Santé du Sénégal). The study was conducted according to the declaration of Helsinki. Informed consent was obtained from all participants prior to the administration of the questionnaire. Data was anonymous and confidential. No compensation either financial or material was given to the interviewees in this survey.

\section{Results}

Socio-demographic characteristics of study population: Overall, 250 subjects were included in this study. The age of selected interviewees ranged from 18 to 77 years with the mean, median and standard deviation of 40.8, 36 and 29.2, respectively. According to age, the study population was mainly constituted by participants aged over 36 years old (51.6\%). Most of respondents were female $58.8 \%$ while male represented $41.2 \%$. Regarding the area of residence, $53.6 \%$ of interviewees reported living in sub-urban area while $42.4 \%$ in urban area. Only $4 \%$ of the study subjects lived in rural area. Most of respondents were married $(51.2 \%)$ or single $(39.5 \%)$. The majority of interviewees were salaried $(25.6 \%)$, or labourer $(16.8 \%)$ or university student (16\%), housewives represented $12.4 \%$. Overall, the participants had acquired primary, secondary and high education with respectively $26 \%, 31.6 \%$ and $25.6 \%$. Few of participants had no education (6\%). Demographic characteristics are shown in Table 1.

\begin{tabular}{|c|c|c|}
\hline Demographic characteristics & Frequency (no.) & Percentage (\%) \\
\hline \multicolumn{3}{|l|}{ Sex } \\
\hline Male & 103 & 41.2 \\
\hline Female & 147 & 58.8 \\
\hline \multicolumn{3}{|l|}{ Age group (years, IQR) } \\
\hline$<26$ & 66 & 26.4 \\
\hline 26-36 & 63 & 25.2 \\
\hline $36-51$ & 61 & 24.4 \\
\hline$>51$ & 60 & 24 \\
\hline \multicolumn{3}{|l|}{ Geographic origin } \\
\hline Urban & 106 & 42.4 \\
\hline Suburban & 134 & 53.6 \\
\hline Rural & 10 & 4 \\
\hline \multicolumn{3}{|l|}{ Marital status } \\
\hline Married & 147 & 51.2 \\
\hline Single & 98 & 39.5 \\
\hline Divorced & 15 & 6.1 \\
\hline Widower & 8 & 3.2 \\
\hline
\end{tabular}


Citation: Lakhe NA, Diallombaye K, Sylla K, Dia Badiane NM, Diop CT, et al. (2018) Knowledge, Attitudes and Practices towards Ebola Virus Disease among Participants in an Ebola Vaccine Trial in Dakar, Senegal. J Trop Dis 6: 276. doi:10.4172/2329-891X.1000276

Page 3 of 9

\begin{tabular}{|l|l|l|}
\hline Occupation & 64 & 25.6 \\
\hline Salaried & 42 & 16.8 \\
\hline Laborer & 40 & 16 \\
\hline University student & 31 & 12.4 \\
\hline Housewives & 29 & 11.6 \\
\hline Unemployed & 25 & 10 \\
\hline Trader & 12 & 4.8 \\
\hline School student & 7 & 2.8 \\
\hline Retired & & \\
\hline Educational level & 65 & 26 \\
\hline Primary & 79 & 31.6 \\
\hline Secondary & 63 & 25.2 \\
\hline University & &
\end{tabular}

\begin{tabular}{|l|l|l|}
\hline Koran & 28 & 11.2 \\
\hline No education & 15 & 6 \\
\hline $\begin{array}{l}\text { Table 1 resumes the socio demographic characteristics of the study population } \\
(\mathrm{N}=250) \text { with predominance of female (58.8\%), age group over } 36 \text { years } \\
(51.6 \%) \text { and married (51.2\%). }\end{array}$
\end{tabular}

Table 1: Demographic characteristics of Ebola vaccine trial participants in SMIT, Dakar, Senegal.

Sources of information on Ebola Virus Disease (EVD): All information sources point to the key role played by television (TV) and radio stations as the first and most widespread source of information on Ebola. Overall $98.8 \%$ and $94 \%$ of respondents reported they first learned about Ebola Virus Disease through the TV and radio respectively (Table 2). The next most common sources of information about Ebola were interpersonal communication with family, friends (84.4\%) and neighbours (79.2\%) (Table 2).

\begin{tabular}{|c|c|c|c|}
\hline Questions & Yes no. (\%) & No no. (\%) & Not sure no. (\%) \\
\hline \multicolumn{4}{|c|}{ Sources of information } \\
\hline TV & $247(98.8)$ & $3(1.2)$ & \\
\hline Radio & $235(94)$ & $15(6)$ & \\
\hline Talking & $211(84.4)$ & $39(15.6)$ & \\
\hline Neighboring & $198(79.2)$ & $52(20.8)$ & \\
\hline Press & $162(64.8)$ & $88(35.2)$ & \\
\hline At work & $139(55.6)$ & $111(44.4)$ & \\
\hline Internet & $118(47.2)$ & $132(52.8)$ & \\
\hline \multicolumn{4}{|l|}{ Symptoms } \\
\hline Vomiting & $212(93.4)$ & $2(0.9)$ & $13(5.7)$ \\
\hline Fever & $210(92.5)$ & $3(1.3)$ & $14(6.2)$ \\
\hline Bleeding & $194(85.5)$ & $10(4.4)$ & $23(10.1)$ \\
\hline Fatigue & $187(82.4)$ & $8(3.5)$ & $32(14.1)$ \\
\hline Diarrhea & $186(81.9)$ & $6(2.6)$ & $35(15.4)$ \\
\hline Headache & $172(75.8)$ & $10(4.4)$ & $45(19.8)$ \\
\hline Muscle pains & $139(61.2)$ & $20(8.8)$ & $68(30)$ \\
\hline Joint pains & $132(58.2)$ & $23(10.1)$ & $72(31.7)$ \\
\hline Loss of appetite & $129(56.8)$ & $18(7.9)$ & $80(35.2)$ \\
\hline Cough & $115(50.7)$ & $30(13.2)$ & $82(36.1)$ \\
\hline \multicolumn{4}{|c|}{ Animals implicated in transmission } \\
\hline Monkey & $225(90.7$ & $3(1.2)$ & $20(8.1)$ \\
\hline Antelope & $49(19.8)$ & $71(28.6)$ & $128(51.6)$ \\
\hline
\end{tabular}


Citation: Lakhe NA, Diallombaye K, Sylla K, Dia Badiane NM, Diop CT, et al. (2018) Knowledge, Attitudes and Practices towards Ebola Virus Disease among Participants in an Ebola Vaccine Trial in Dakar, Senegal. J Trop Dis 6: 276. doi:10.4172/2329-891X.1000276

Page 4 of 9

\begin{tabular}{|c|c|c|c|}
\hline Bat & $183(73.8)$ & $16(6.5)$ & $49(19.8)$ \\
\hline Snakes & $50(20.2)$ & $82(33.1)$ & $116(46.8)$ \\
\hline Dogs & $81(32.7)$ & $68(27.4)$ & 99 (39.9) \\
\hline Cats & $66(26.6)$ & $77(31.1)$ & $105(42.3)$ \\
\hline Sheep & $12(4.8)$ & $169(68.2)$ & $67(27)$ \\
\hline Good knowledge about reservoir & $183(73.8)$ & $65(26.2)$ & \\
\hline \multicolumn{4}{|l|}{ Transmission mode } \\
\hline Blood & $186(74.7)$ & $15(6)$ & $48(19.3$ \\
\hline Sexual route & $149(59.8)$ & $30(12.1)$ & $70(28.1)$ \\
\hline Saliva & $188(75.5)$ & $12(4.8)$ & $49(19.7)$ \\
\hline Vomiting & $209(84.3)$ & $10(4)$ & $29(11.7)$ \\
\hline Stools & $186(74.7)$ & $15(6)$ & $48(19.3$ \\
\hline Water & $123(49.4)$ & $62(24.9)$ & $64(25.7)$ \\
\hline Air & $121(48.6)$ & $60(24.1)$ & $68(27.3)$ \\
\hline Mosquito bites & $109(43.8)$ & $88(35.3)$ & $52(20.9)$ \\
\hline Bush meat & $214(85.9)$ & $12(4.8)$ & $23(9.2)$ \\
\hline Domestic meat & $41(16.5)$ & $157(63.1)$ & $51(20.5)$ \\
\hline Contact with deceased patient from Ebola & $220(88.4)$ & $8(3.2)$ & $21(8.4)$ \\
\hline Talking with patient without touching & $126(50.6)$ & $91(36.6)$ & $32(12.9)$ \\
\hline Transmission by banknotes & $116(46.6)$ & $89(35.7)$ & $44(17.7)$ \\
\hline Good knowledge about transmission & $55(22.1)$ & $194(77.9)$ & \\
\hline Stigmatization & $123(49.2)$ & $127(50.8)$ & \\
\hline
\end{tabular}

Table 2: Participants sources of information on Ebola and knowledge about symptoms, animals involved in transmission, reservoir, transmission mode and stigmatization.

Knowledge about symptoms, animals involved in transmission, reservoir, transmission mode and stigmatization: The results of this study showed that 52 interviewees $(60.8 \%)$ have knowledge about Ebola Virus Disease. Overall, the majority of the respondents (88.8\%) had knowledge regarding Ebola signs and symptoms. The main symptoms identified by interviewees were vomiting $(93 \%)$, fever $(93 \%$ and bleeding (85\%).

Among interviewees, the majority identified the cause of EVD to be wild by animals such as monkeys (91\%) and bats (74\%). Also, $87 \%$ of them affirmed that domestic animals did not play any role in Ebola transmission. According to the definition, $73.8 \%$ of the respondents had good knowledge about reservoir.

Concerning the transmission, the respondents identified the contact with infected person or death of Ebola as the main transmission mode (88.4\%). Positive response about transmission by fluids such as blood, stools and vomiting were given by interviewees with respectively $75 \%$,
$75 \%$ and $84 \%$. However, respondents considered that transmission is possible with having a discussion with infected person without being in touch him (50.6\%). The others transmission mode identified by interviewees: mosquito bites (44\%), contact with banknotes (47\%) and being in touch someone who was in contact with infected person (47\%). Good knowledge about transmission represented $22.1 \%$.

Nearly half of the participants had stigmatization attitudes (49.2\%). One-hundred-sixty-two pledge for closing the borders, when 157 (62.8\%) would avoid citizen from countries affected by EVD whether they are ill or not. Among the participants, 79 stopped consuming products from these countries. Relating data are represented in Table 2.

Knowledge and attitudes of prevention means of Ebola Virus Disease (EVD): The majority of the respondents estimated that EVD could be preventable by washing hands daily (97.2\%). 186 interviewees (74.4\%) said that increasing washing hands could help to prevent EVD. Hand washing 5 to 10 times per day was done by $48.4 \%$ of study 
Citation: Lakhe NA, Diallombaye K, Sylla K, Dia Badiane NM, Diop CT, et al. (2018) Knowledge, Attitudes and Practices towards Ebola Virus Disease among Participants in an Ebola Vaccine Trial in Dakar, Senegal. J Trop Dis 6: 276. doi:10.4172/2329-891X.1000276

Page 5 of 9

participants and 138 of the respondents $(72.6 \%)$ washed their hands with soap and hypochlorite (Table 3 ).

\begin{tabular}{|c|c|c|}
\hline Changing attitudes by hand washing & Frequency (no.) & Percentage (\%) \\
\hline \multicolumn{3}{|l|}{ Prevention by hand washing } \\
\hline Yes & 240 & 97.2 \\
\hline No & 7 & 2.8 \\
\hline \multicolumn{3}{|l|}{ Increase hand washing } \\
\hline Yes & 186 & 74.4 \\
\hline No & 64 & 25.6 \\
\hline \multicolumn{3}{|l|}{ Hand washing frequency (per day) } \\
\hline Less than 5 & 44 & 23.2 \\
\hline 5 to 10 & 92 & 48.4 \\
\hline More than 10 & 54 & 28.4 \\
\hline \multicolumn{3}{|l|}{ Hand washing methods } \\
\hline Soap & 47 & 24.7 \\
\hline Soap and Hypochlorite & 138 & 72.6 \\
\hline Hypochlorite & 5 & 2.6 \\
\hline
\end{tabular}

Table 3 shows behavioural change regarding hand washing, the majority of the respondents $(97.2 \%)$ established hand washing as a mean of prevention and $74.4 \%$ increase hand washing.

Table 3: Ebola prevention by hand-washing and behavior change among participants in the vaccine trial in SMIT, Dakar, Senegal.

Knowledge and motivation about vaccine: For the majority of respondents $(92.8 \%)$, the role of vaccine was to prevent illness. Less than half $(45.6 \%)$ knew that another role was to reduce the severity of diseases. For slightly two third of the participants, immunization was without any risk and $88 \%$ thought that Ebola vaccine was available. The main motivation for being part to this study was confidence in doctors (79.6\%) and example given by the medical profession $(75.6 \%)$. Only $2 \%$ of participants admitted that their motivation was financial. See Table 4 for these results.

\begin{tabular}{|l|l|l|l|}
\hline Questions & $\begin{array}{l}\text { Yes no. } \\
(\%)\end{array}$ & No no. (\%) & $\begin{array}{l}\text { Not sure no. } \\
(\%)\end{array}$ \\
\hline Role of vaccine & $232(92.8)$ & $13(5.2)$ & $5(2)$ \\
\hline Prevent illness & $114(45.6)$ & $107(42.8)$ & $29(11.6)$ \\
\hline Reduce the severity of the disease & $78(31.2)$ & $134(53.6)$ & $38(15.2)$ \\
\hline Existence of immunization risks & $220(88)$ & $18(7.2)$ & $1254.8)$ \\
\hline Availability of Ebola vaccine & \multicolumn{2}{|l|}{} \\
\hline Motivation for vaccine & $95(38)$ & $155(62)$ & \\
\hline Knowledge of doctors & $199(79.6)$ & $51(20.4)$ & \\
\hline Confidence in doctors & $189(75.6)$ & $61(24 ; 4)$ & \\
\hline $\begin{array}{l}\text { Example given by the medical } \\
\text { profession }\end{array}$ & & & \\
\hline
\end{tabular}

\begin{tabular}{|l|l|l|l|}
\hline Example given by a relative & $83(32.2)$ & $167(66.8)$ & \\
\hline Example given by a celebrity & $34(13.6)$ & $216(86.4)$ & \\
\hline For money & $5(2)$ & $245(98)$ & \\
\hline
\end{tabular}

Table 4 illustrates knowledge and motivation of the respondents towards vaccine, 232 of the 250 pointed out the preventing role of vaccine and being part of the Ebola vaccine trial was motivated by the confidence in doctors $(79.6 \%)$ and example given by the medical staff $(75.6 \%)$.

Table 4: Knowledge and motivation of the respondents towards vaccine.

Association between level of knowledge on EVD and key characteristics: Male participants showed a higher level of knowledge about virus reservoir than female but the difference was not significant $(\mathrm{p}=0.38)$. The findings of the study also showed that knowledge towards the virus reservoir were significantly higher among participants aged between 36 and 51 years old $(\mathrm{p}=0.5)$. Interviewees living in suburban and rural area had higher rate of positive response $(79,02 \%)$ concerning virus reservoir comparing to those in urban area $(66.02 \%)$ without significant difference $(\mathrm{p}=0.07)$. Respondents with high level of education (75.85\%) had more knowledge concerning virus reservoir than those without education (62.5\%). The results are shown in Table 5.

Regarding the transmission mode, the difference was not significant between male and female interviewees $(\mathrm{p}=0.96)$. Generally, knowledge about transmission route was higher in the participants aged between 36 and 51 years old $33.3 \%(n=20)$, in those living in suburban and rural area $28.5 \%(\mathrm{n}=48)$, in married interviewees $29.1 \%(\mathrm{n}=18)$ and in educated participants $31 \%(n=13)$ with a significant difference. Association between knowledge of transmission mode and demographic characteristics are represented in Table 5.

\begin{tabular}{|c|c|c|c|c|c|c|c|c|c|c|}
\hline \multirow{3}{*}{ Variables } & \multicolumn{4}{|c|}{ Reservoir } & \multirow{3}{*}{$\mathbf{p}$} & \multicolumn{4}{|c|}{$\begin{array}{l}\text { EVD } \\
\text { mode }\end{array}$} & \multirow{3}{*}{$\mathbf{p}$} \\
\hline & \multicolumn{2}{|l|}{ No } & \multicolumn{2}{|l|}{ Yes } & & \multicolumn{2}{|l|}{ No } & \multicolumn{2}{|l|}{ Yes } & \\
\hline & No. & (\%) & No. & $(\%)$ & & No. & $(\%)$ & No. & (\%) & \\
\hline \multicolumn{11}{|l|}{ Sex } \\
\hline Male & 24 & 23.3 & 79 & 76.7 & 0.38 & 80 & 77.7 & 23 & 22.3 & 0.96 \\
\hline Female & 41 & 28.3 & 104 & 71.7 & & 113 & 77.9 & 32 & 22.1 & \\
\hline \multicolumn{11}{|c|}{ Age group (years, IQR) } \\
\hline$<26$ & 21 & 31.8 & 45 & 68.2 & & 60 & 92.3 & 5 & 7.7 & \\
\hline $26-36$ & 17 & 27 & 46 & 73 & 0.5 & 49 & 77.8 & 14 & 22.2 & 0.005 \\
\hline $36-51$ & 12 & 20.3 & 47 & 79.7 & & 40 & 66.7 & 20 & 33.3 & \\
\hline$>51$ & 15 & 25.4 & 44 & 74.6 & & 44 & 73.3 & 16 & 26.7 & \\
\hline \multicolumn{11}{|c|}{ Geographic origin } \\
\hline Urban & 35 & 34 & 68 & 66 & 0.074 & 90 & 87.4 & 13 & 12.6 & 0.01 \\
\hline Other & 30 & 21 & 113 & 79 & & 103 & 71.5 & 41 & 28.5 & \\
\hline \multicolumn{11}{|c|}{ Marital status } \\
\hline Married & 30 & 23.8 & 96 & 76.2 & 0.125 & 90 & 70.9 & 37 & 29.1 & 0.024 \\
\hline
\end{tabular}


Citation: Lakhe NA, Diallombaye K, Sylla K, Dia Badiane NM, Diop CT, et al. (2018) Knowledge, Attitudes and Practices towards Ebola Virus Disease among Participants in an Ebola Vaccine Trial in Dakar, Senegal. J Trop Dis 6: 276. doi:10.4172/2329-891X.1000276

Page 6 of 9

\begin{tabular}{|c|c|c|c|c|c|c|c|c|c|c|}
\hline Other & 35 & 29.4 & 84 & 70.6 & & 101 & 84.9 & 18 & 15.1 & \\
\hline \multicolumn{11}{|l|}{ Education } \\
\hline Education & 50 & 24.2 & 157 & 75.9 & 0.401 & 164 & 79.6 & 42 & 20.4 & 0.028 \\
\hline $\begin{array}{l}\text { No } \\
\text { Education }\end{array}$ & 15 & 37.5 & 25 & 62.5 & & 29 & 69 & 13 & 31 & \\
\hline \multicolumn{11}{|c|}{$\begin{array}{l}\text { Table } 5 \text { shows association between knowledge level on reservoir and } \\
\text { transmission mode towards EVD and key characteristics, respondents in } \\
\text { suburban and rural areas, with education and married ones were more likely to } \\
\text { possess good knowledge of EVD transmission mode (p-value: } 0.01,0.028 \text { and } \\
0.024 \text { respectively) than their counterparts. No demographic characteristic was } \\
\text { associated to good knowledge of the reservoir. }\end{array}$} \\
\hline
\end{tabular}

Table 5: Association between knowledge level on reservoir and transmission mode towards EVD and key characteristics of the participants in the vaccine trial in SMIT, Dakar, Senegal.

About stigmatization, it was higher in female (54.1\%) than male (42.7\%), 26-36 age group, married (55.9\%) and those with no education $(57.1 \%)$ but the difference was not statistically significant. Stigmatization was significantly higher in those expressing fear $(58.1 \%$; $\mathrm{p}=0.000)$ and in respondents living in suburban and rural areas $(52.4$ $\mathrm{p}=0.020$ ) (Table 6).

\begin{tabular}{|c|c|c|c|c|c|}
\hline \multirow[t]{3}{*}{ Variables } & \multicolumn{4}{|c|}{ Stigmatization } & \multirow[t]{3}{*}{ p } \\
\hline & \multicolumn{2}{|l|}{ No } & \multicolumn{2}{|l|}{ Yes } & \\
\hline & No. & $(\%)$ & No. & $(\%)$ & \\
\hline \multicolumn{6}{|l|}{ Sex } \\
\hline Male & 59 & (57.3) & 44 & $(42.7)$ & \multirow[t]{2}{*}{0.077} \\
\hline Female & 67 & $(45.9)$ & 79 & $(54.1)$ & \\
\hline \multicolumn{6}{|c|}{ Age group (years, IQR) } \\
\hline$<26$ & 40 & $(60.6)$ & 26 & $(39.4)$ & \multirow[t]{2}{*}{0.096} \\
\hline $26-36$ & 33 & $(52.4)$ & 30 & $(47.6)$ & \\
\hline
\end{tabular}

\begin{tabular}{|c|c|c|c|c|c|}
\hline $36-51$ & 40 & (66.7) & 20 & (33.3) & \\
\hline$>51$ & 44 & (73.3) & 16 & (27.7) & \\
\hline \multicolumn{6}{|c|}{ Geographic origin } \\
\hline Urban & 55 & $(52.9)$ & 49 & $(47.1)$ & \multirow[t]{2}{*}{0.020} \\
\hline Other & 70 & (48.6) & 74 & (52.4) & \\
\hline \multicolumn{6}{|l|}{ Marital status } \\
\hline Married & 56 & $(44.1)$ & 71 & $(55.9)$ & \multirow[t]{2}{*}{0.053} \\
\hline Other & 70 & $(58.3)$ & 50 & $(41.7)$ & \\
\hline \multicolumn{6}{|l|}{ Education } \\
\hline Education & 108 & $(52.2)$ & 99 & $(47.8)$ & \multirow[t]{2}{*}{0.064} \\
\hline No Education & 18 & $(42.9)$ & 24 & $(57.1)$ & \\
\hline \multicolumn{6}{|l|}{ Fear } \\
\hline Yes & 75 & (41.7) & 105 & $(58.3)$ & \multirow[t]{2}{*}{0.000} \\
\hline No & 51 & (73.9) & 18 & (26.1) & \\
\hline
\end{tabular}

Table 6 shows association between stigmatization towards EVD and key characteristics, respondents were more likely to have stigmatization attitudes when they lived in suburban or rural settings and when expressed fear ( $p$-value: 0.020 and 0.000 respectively).

Table 6: Association between stigmatization towards EVD and key characteristics of the participants in the vaccine trial in SMIT, Dakar, Senegal.

Concerning the hand washing attitudes, female respondents had a high rate of positive response $(76.7 \%)$ comparing to male respondents (70.9\%). Interviewees aged over 51 years old and those living in suburban and rural area had significantly increased hand washing $(p=0.03)$. Matrimonial status and educational level had no influence on hand washing attitudes. These results are represented in Table 7.

\begin{tabular}{|c|c|c|c|c|c|}
\hline \multirow[t]{3}{*}{ Variables } & \multicolumn{4}{|c|}{ Increase hand washing } & \multirow[t]{3}{*}{ p } \\
\hline & \multicolumn{2}{|l|}{ Yes } & \multicolumn{2}{|l|}{ No } & \\
\hline & No. & (\%) & No. & (\%) & \\
\hline \multicolumn{6}{|l|}{ Sex } \\
\hline Male & 73 & $(70.9)$ & 30 & (29.1) & \multirow[t]{2}{*}{0.29} \\
\hline Female & 112 & $(76.7)$ & 34 & (23.3) & \\
\hline \multicolumn{6}{|c|}{ Age group (years, IQR) } \\
\hline$<26$ & 49 & $(74.2)$ & 17 & $(25.8)$ & \multirow[t]{4}{*}{0.033} \\
\hline $26-36$ & 48 & (76.2) & 15 & (23.8) & \\
\hline $36-51$ & 51 & (85) & 9 & (15) & \\
\hline$>51$ & 37 & $(61.6)$ & 23 & (38.3) & \\
\hline
\end{tabular}




\begin{tabular}{|c|c|c|c|c|c|}
\hline Urban & 76 & (73.1) & 28 & (26.9) & \multirow[t]{3}{*}{0.03} \\
\hline Suburban & 104 & (77.6) & 30 & (22.4) & \\
\hline Rural & 4 & (40) & 6 & (60) & \\
\hline \multicolumn{6}{|l|}{ Marital status } \\
\hline Married & 98 & (77.2) & 26 & (22.8) & \multirow[t]{2}{*}{0.65} \\
\hline Other & 85 & (70.8) & 35 & $(29.2)$ & \\
\hline \multicolumn{6}{|l|}{ Education } \\
\hline Education & 152 & (73.4) & 55 & (26.6) & \multirow[t]{2}{*}{0.52} \\
\hline No Education & 33 & (78.6) & 9 & (21.4) & \\
\hline \multicolumn{6}{|l|}{ Fear } \\
\hline Yes & 147 & (81.7) & 33 & (18.3) & \multirow[t]{2}{*}{0.000} \\
\hline No & 38 & (55.1) & 31 & $(44.9)$ & \\
\hline
\end{tabular}

Table 7: Association between increase hand washing for preventing EVD and key characteristics of the participants in the vaccine trial in SMIT, Dakar, Senegal.

\section{Discussion}

This study assessed the knowledge, attitude, and practice of participants of an Ebola vaccine trial towards EVD.

The majority of the population consisted of adult subjects, which falls under the participation criteria of this study. It is also remarkable for the predominance of women. The main sources of information identified were radio and TV. During this period, many commercials were broadcast and messages delivered on symptoms and preventive measures of EVD. This is another testimony that television or radio are the preferential channels for health information in our regions [9-11] unlike the USA where the main source of information was internet [12]. Interposal communication at work or in the neighbouring was another important source of information; however the quality of this information was not certified. Participants' educational level was quite high since most had reached secondary education level.

All the interviewees had heard about EVD and for the great majority of them, the level of knowledge regarding the signs was very high. If the late signs are well represented, the early signs of the disease are well recovered even though it is less. This is a good point given that failure of early signs of EVD leads to a late diagnosis and then to the spread of the disease.

The level of knowledge of vaccine trial participants regarding the main modes of transmission of EVD was very low as previously demonstrated in the same area [13] and also elsewhere [14,15]. Some misconceptions are persistent such as transmission by air or by bank notes and had already been highlighted in other studies [10,11,13,15-17].

The different mode of transmission of the virus were known either by direct contact with an animal vector or through the bodily fluids of EVD patient. In this sense, our results are similar to those already described [17]. In our study, knowledge of the transmission mode was not influenced by gender but rather by education level, geographic origin or marital status. Studies in Nigeria and Uganda show that possessing at least secondary education were positively associated with satisfactory general knowledge $[9,11]$. This relies on the fact that education is a key determinant of knowledge especially concerning health and health seeking behaviours. Knowledge of transmission mode increased significantly with age up to age 51. It was therefore higher in the labour force. Geographic origin was positively correlated with a good knowledge of transmission mode. This knowledge was significantly higher in patients from suburban and rural areas. This fact is very informative as respondents who live in the city have better access to information via many means of communication whether it is television, radio, print or even internet thanks to smartphones or tablets. In order to diminish risk, it will be crucial to investigate in the anthropologic field about urban and rural population behaviors. Knowledge on mode of transmission is important as EVD can be prevented using hygiene practices measures such as hand washing. It was already demonstrated that good knowledge about transmission, enhances the adoption of preventing measures [18].

The knowledge of the reservoir of EVD was very high in our study as well as that of Jalloh \& al. [10] unlike what was reported in Uganda [9]. The main sources of transmission found in our study but also in others, were monkeys and bats $[9,19]$.

Our study reveals mistrust towards countries affected by the epidemic. In fact, a great majority of respondents would avoid citizens from these countries whether they are ill or not and 162 of them would be in favour of closing the borders. Actually, Senegal notified one imported case and at that time the borders were shut down. Regarding stigmatization, our study shows also that several respondents was not consuming products coming from the countries affected by the outbreak. Stigmatization attitudes were significantly higher in respondents not residing in urban areas. This fact is however paradoxical since this same group had a better knowledge of 
transmission mode of the disease. The causes would be interesting to look for, especially in cultural beliefs. This is especially true since the stigma is closely related to the misconceptions on transmission mode of EVD. It is also already known that stigma has implications for EVD prevention and control [20]. Failure to take this into account could seriously hamper efforts to prevent this disease.

Several studies underscored that EVD patients suffer stigma even after recovering $[9,17,21,22]$. This has led to the fact that in some communities, patients have been neglected or some have not been reported for treatment. In a future study, it can be interesting to study the patients with Ebola who did not report for treatment due to stigmatization in order to know the outcome of their illness.

In our study, even hand washing was known nearly by everyone as a preventing measure of Ebola, in fact less than $75 \%$ change their behaviour by increasing hand washing. Factors related to increasing this measure were the residence and marital status rather than sex or educational level. At the time, an advertising campaign was broadcast through television and radio on EVD symptoms and emphasizing hand-washing techniques. But studies have showed that communicating knowledge about why people should wash their hands with soap is often insufficient to induce behavioural changes in practice especially in situations where alternative health priorities exist [23]. Also, the main reason for change in hand washing practices was because EVD causes death [24]. In our study, fear was significantly related to increase of hand washing. When fear is the main factor of a behaviour change this cannot be sustained [24]. In illustration, in a recent study in Nigeria focusing on hand hygiene practices post Ebola virus disease outbreak in a teaching hospital, majority of respondents who were healthcare workers had a poor practice of hand hygiene for infection control [25].

In addition, behavioural change about hand washing was significantly more perceivable in urban or suburban settings than rural ones $(p=0,030)$. This can be explained by the fact that urban and suburban areas have more access to health information or water and are generally more educated.

Addressing vaccine, the majority of our respondents knew vaccine as a mean to prevent infectious diseases. However, in our study only few noted that immunization can be at risk such as vaccine-related serious adverse events. What was curious is that the overall majority of the participants answered that an Ebola vaccine was already available given that they were being part of an Ebola vaccine trial. In a study in Sierra Leone, only about one third (31.7\%) of the participants knew the vaccine was under clinical trials [26]. Our participants were mostly motivated by confidence inspired by doctors and example given by a medical staff. Such results can be explained by the facts that these site priors' investigators of this clinical trial were well known and valued in the community. It may play a role to these findings. Subsequently to better ensure the acceptability of the Ebola vaccine, one can rely on such figures. Also, free or low-priced vaccine could increase the vaccination acceptability of the general community population [26]. In a Nigerian study, a higher proportion of respondents willing to participate in clinical trials were willing to receive vaccine [27].

The limitations of this study were that respondents were participating to a vaccine trial which can play a role in the demographic characteristic of this population. Participants were healthcare workers as well as from the community. Another limitation is the fact that the participants in this study are involved in the vaccine trial for EVD mean they already have a foreknowledge of EVD compared to the general Senegalese population hence this survey findings may not in some ways necessarily represent what is obtainable in the general Senegalese population. This study is also limited by its cross-sectional design and the fact that some respondents could have given socially acceptable answers to some questions.

\section{Conclusion}

In conclusion, the study revealed that participants in Ebola vaccine trial are slightly knowledgeable about transmission mode and have a good attitude towards control and prevention of EVD. Education and not residing in an urban area are significantly related to good knowledge on transmission mode towards Ebola virus disease. Classical media play important roles in increasing awareness of EVD. Stigmatization is persistent and is associated significantly to the geographic origin. Respondents increase hand washing, to sustain this change of behaviour, campaign in mass media must persist. Vaccine was known as a major mean for preventing diseases and to further ensure the acceptability of Ebola virus vaccine, campaign, using medical figures can play a key role.

\section{Acknowledgments}

This study was not funded. The authors thank Drs. Mame Ndack Djitté Ngom and Awa Gueye Mbaye for their participation in the survey and all the participants of the Ebola vaccine Trial at Fann Hospital.

\section{Conflicts of Interest}

The authors declare no conflict of interest.

\section{References}

1. Breman JG, Johnson KM, van der Groen G, Robbins CB, Szczeniowski MV, et al. (1999) A search for Ebola virus in animals in the Democratic Republic of the Congo and Cameroon: ecologic, virologic, and serologic surveys, 1979-1980. Ebola Virus Study Teams. J Infect Dis 179: S139-S147.

2. Tutin CEG (2000) Ecology and social organization of primates of the African rainforest: helps to understand the transmission of retroviruses. Bull Soc Pathol Exot 157: 61.

3. Omoleke SA, Mohammed I, Saidu Y (2016) Ebola viral disease in West Africa: a threat to global health, economy and political stability. J Public Health Afr 7: 1.

4. Spengler JR, Ervin ED, Towner JS, Rollin PE, Nichol ST (2016) Perspectives on West Africa Ebola Virus Disease Outbreak, 2013-2016. Emerg Infect Dis 6: 956-963.

5. Bolanle AA (2018) Multinational perspective on health care delivery: private versus government. J Appl Biotechnol Bioeng 1: 1-9.

6. WHO, Statement on the 1st meeting of the IHR Emergency Committee on the 2014 Ebola outbreak in West Africa WHO.

7. WHO (2006) WHO. Ebola Situation Report.

8. Henao-Restrepo AM, Longini IM, Egger M, Dean NE, Edmunds WJ, et al. (2015) Efficacy and effectiveness of an rVSV-vectored vaccine expressing Ebola surface glycoprotein: interim results from the Guinea ring vaccination cluster-randomised trial. The Lancet 386: 857-866.

9. Nyakarahuka L, Skjerve E, Nabadda D, Sitali DC, Mumba C, et al. (2017) Knowledge and attitude towards Ebola and Marburg virus diseases in Uganda using quantitative and participatory epidemiology techniques. PLoS Negl Trop Dis 11: e0005907.

10. Jalloh MF, Sengeh P, Monasch R, Jalloh MB, DeLuca N, et al. (2017) National survey of Ebola-related knowledge, attitudes and practices 
Citation: Lakhe NA, Diallombaye K, Sylla K, Dia Badiane NM, Diop CT, et al. (2018) Knowledge, Attitudes and Practices towards Ebola Virus Disease among Participants in an Ebola Vaccine Trial in Dakar, Senegal. J Trop Dis 6: 276. doi:10.4172/2329-891X.1000276

Page 9 of 9

before the outbreak peak in Sierra Leone: August 2014. BMJ Glob Health 2: $\mathrm{e} 000285$.

11. Gidado S, Oladimeji AM, Roberts AA, Nguku P, Nwangwu IG, et al. (2015) Public knowledge, perception and source of information on ebola virus disease - lagos, Nigeria; september, 2014. PLoS Curr.

12. Rolison JJ, Hanoch Y (2015) Knowledge and risk perceptions of the Ebola virus in the United States. Prev Med Rep 2: 262-264.

13. Lanièce C, Sow K, Desclaux A (2016) Security agents on the front line against Ebola: roles, perceptions and knowledge in Fann Teaching Hospital, Dakar, Senegal. Bull Soc Pathol Exot 109: 303-308.

14. Iliyasu G, Ogoina D, Otu AA, Dayyab FM, Ebenso B, et al. (2015) A multi-site knowledge attitude and practice survey of Ebola Virus Disease in Nigeria. PLOS ONE 10: e0135955.

15. Kobayashi M, Beer KD, Bjork A, Chatham-Stephens K, Cherry CC, et al. (2015) Community knowledge, attitudes, and practices regarding Ebola Virus Disease-five counties, Liberia, September-October, 2014. MMWR Morb Mortal Wkly Rep 64: 714-718.

16. Alfaki MM, Salih AMM, Elhuda DA, Egail MS (2016) Knowledge, attitude and practice of health care providers toward Ebola virus disease in hotspots in Khartoum and White Nile states, Sudan, 2014. Am J Infect Control 44: 20-23.

17. Adongo PB, Tabong PT-N, Asampong E, Ansong J, Robalo M, et al. (2016) Beyond knowledge and awareness: Addressing misconceptions in Ghana's preparation towards an outbreak of Ebola Virus Disease. PloS One 11: e0149627.

18. Janjua NZ, Razaq M, Chandir S, Rozi S, Mahmood B (2007) Poor knowledge-predictor of nonadherence to universal precautions for blood borne pathogens at first level care facilities in Pakistan. BMC Infect Dis 7: 81.
19. Olowookere SA, Abioye-Kuteyi EA, Adepoju OK, Esan OT, Adeolu TM, et al. (2015) Knowledge, Attitude, and practice of health workers in a tertiary hospital in Ile-Ife, Nigeria, towards Ebola Viral Disease. J Trop Med 2015: 1-6.

20. Barrett R, Brown PJ (2008) Stigma in the time of influenza: social and institutional responses to pandemic emergencies. J Infect Dis 197: S34S37.

21. Davtyan M, Brown B, Folayan MO (2014) Addressing Ebola-related stigma: lessons learned from HIV/AIDS. Glob Health Action 7: 26058.

22. Jalloh MF, Robinson SJ, Corker J, Li W, Irwin K, et al. (2017) Knowledge, attitudes, and practices related to Ebola Virus Disease at the end of a National Epidemic - Guinea, August 2015. MMWR Morb Mortal Weekly Rep 41: 1109-1115.

23. Aboud FE (2010) Virtual special issue introduction: Health behaviour change. Soc Sci Med 71: 1897-1900.

24. Ilesanmi OS, Alele FO (2015) The effect of Ebola Virus Disease outbreak on hand washing among secondary school students in Ondo State Nigeria, October, 2014. Pan Afr Med J 22: 24.

25. Martins SO, Osiyemi AO (2017) Hand hygiene practices post ebola virus disease outbreak in a nigerian teaching hospital. Ann Ib Postgrad Med 15: 16-22.

26. Huo X, Shi G, Li X, Lai X, Deng L, et al. (2016) Knowledge and attitudes about Ebola vaccine among the general population in Sierra Leone. Vaccine 34: 1767-1772.

27. Olowookere SA, Abioye-Kuteyi EA, Adekanle O (2016) Willingness to participate in Ebola viral disease vaccine trials and receive vaccination by health workers in a tertiary hospital in Ile-Ife, Southwest Nigeria. Vaccine 34: 5758-5761. 